\title{
DAZL wt Allele
}

National Cancer Institute

\section{Source}

National Cancer Institute. DAZL wt Allele. NCI Thesaurus. Code C114633.

Human DAZL wild-type allele is located in the vicinity of 3p24 and is approximately $84 \mathrm{~kb}$ in length. This allele, which encodes deleted in azoospermia-like protein, is involved in male and female gametogenesis. 